\title{
LITERATURA DE SE ENCHER OS OLHOS
}

Alessandra Gomes da SILVA

Palavra puxa palavra, uma idéia traz outra, e assim se faz um livro, um governo, ou uma revolução, alguns dizem que assim é que a natureza compôs as suas espécies."

"Histórias sem Data: Primas de Sapucaia", Machado de Assis

Livros não mudam o mundo, quem muda o mundo são as pessoas. Os livros só mudam as pessoas”

Mario Quintana

\section{A leitura e a nossa relação com os livros}

Este breve texto tem como principal objetivo tentar descrever paixões. Paixão pelo ensino, necessária a todo aquele que se dedica ao árduo ofício de ser professor, paixão por livros e textos, único mecanismo realmente eficiente para garantir a formação de novos leitores. E é com esse sentimento que buscarei tecer alguns comentários a respeito do ensino de literatura, em um contexto muito especial de educação de alunos surdos, tendo como base um estágio que fiz na disciplina de literatura, em turmas de ensino médio, do Instituto de Educação de Surdos (INES ).

Por conseguinte, inicio lembrando que todos somos construídos por textos. O prazer de ler e contar histórias é inerente ao próprio ser humano. Lemos muito antes de aprendermos a ler, imersos em costumes da tradição oral, ouvimos histórias e nos apaixonamos pela literatura sem nos darmos conta de como ela se chama ou mesmo do que significa o ato de ler.

A grande questão, então, é de como manter e desenvolver tal prazer pela leitura durante a vida escolar do indivíduo, tornando-o um leitor eficiente e ‘apaixonado' pelos livros, mesmo em condições lingüísticas diferenciadas como é o exemplo do aluno surdo. Assim, é pensando sempre na importância da leitura para a constituição do sujeito que buscaremos analisar a relação entre texto, literatura e ensino.

\section{Literatura na escola}


Na escola, o ensino de literatura diz respeito a permitir o acesso a um imaginário coletivo que é patrimônio cultural de toda a nossa sociedade. Não interessa, nesse espaço, recorrer à literatura apenas como um ‘trabalho', texto literário não é para ser lido para se fazer uma avaliação, um tipo de questionário, com perguntas a cerca do autor e de alguns aspectos isolados do livro. Literatura é bem mais do que isso.

A escola é o lugar no qual se deve propiciar espaços de experimentação do texto literário, possibilitar a troca de experiências de leituras entre os alunos, incentivar o hábito de ler e a sua reflexão crítica. Para isso, precisamos instrumentalizar nosso aluno de modo que ele consiga depreender, a partir da leitura, as diferentes possibilidades de interpretação de um texto, não esquecendo que todo texto literário é plural, é dialógico, os sentidos precisam ser negociados e os leitores são parte ativa nesse processo. Cabe a escola, portanto, potencializar o desenvolvimento plenos das habilidades humanas, além de humanizar o próprio sujeito, capacidades construídas por meio de um contato com a arte, possíveis a partir da literatura.

Não se pode ignorar ainda que, neste contexto atual, o ensino de literatura transforma-se em um grande desafio para a escola, pois tornam-se necessárias novas alternativas de seduzir o leitor para a literatura, uma vez que os meios de comunicação disputam com os livros o espaço e o gosto dos alunos. Deve-se entender que a literatura, por sua vez, se faz com o desenvolvimento do hábito de leitura, o que só é possível com continuidade e quando se consegue despertar o interesse do próprio aluno para os textos literários.

\section{O caso específico dos alunos surdos}

De acordo com a LDB, no tocante ao ensino voltado para "alunos portadores de necessidades especiais, os currículos, métodos, técnicas, enquanto recursos educativos e organização específicos, fazem-se necessários para atender às necessidades próprias desses alunos”. A escola pode e deve, portanto, organiza-se de modo a garantir que esses alunos tenham acesso aos mais diferentes conteúdos e que ocorra a sua efetivamente aprendizagem.

Nesse contexto, dificilmente seria possível ao aluno surdo, cuja língua materna e de instrução é a LIBRAS, apreender os conteúdos de literatura sem um grande domínio da língua portuguesa escrita, principal instrumento de veiculação de todo um patrimônio 
cultural e literário. Ter acesso a tais conteúdos em sua língua materna é direito do surdo, garantido por lei, mas viabilizar esse ensino ainda se mostra como um considerável desafio.

A proposta de trabalho realizada nas aulas de literatura e aqui apresentada foi construída inicialmente com a utilização da tradução dos textos literários para a LIBRAS, por meio de vídeos nos quais apareciam o texto em língua portuguesa e um intérprete, responsável por traduzi-lo para a língua brasileira de sinais. Esses materiais ainda não apresentam um grande número de textos, mas já se encontram produzidos e comercializados por editoras específicas. Podem ser citados como exemplos os textos ' A cartomante’, de Machado de Assis e 'Iracema’, de José de Alencar, além de alguns títulos infanto-juvenis.

Em um segundo momento, tem-se a discussão desses textos e o uso de filmes sobre o tema, sejam filmes realizados a partir do livro, adaptações, tais como 'A cartomante', ou 'Iracema', sejam filmes sobre o contexto no qual a obra foi produzida, ou, ainda, filmes de referência para uma determinada época literária, o que permite a ampliação dos conteúdos vistos em língua de sinais, bem como um maior conhecimento acerca do contexto da obra. Uma base visual pode tornar-se atraente para qualquer aluno, mas, com certeza, é fundamental para os alunos surdos, que têm como língua natural, a língua de sinais, uma língua por si mesma, visual.

Logo, a participação e interesse dos alunos são visíveis, o gosto pela literatura, pelo contar e compreender histórias, crescentes. Como em várias escolas, novos mecanismos são buscados para divulgarem os textos literários e desenvolverem o prazer pela leitura. Por conseguinte, para o aluno surdo, em particular, a dificuldade com a língua portuguesa era uma 'barreira' para a imersão nessa cultura letrada.

Nesse sentido, o cinema transforma-se em suporte, um caminho, uma via de acesso do aluno ao texto. Além disso, a incorporação das novas tecnologias no espaço escolar proporciona ao aluno um novo campo de conhecimentos e possibilidades mesmo de utilizálas no seu dia a dia. O filme não substitui o livro, pelo contrário, desperta nos alunos o interesse em ler, em saber como as histórias vistas foram criadas, estão escritas nos livros, há um grande desejo de apropriação dos textos literários e do próprio português, compreendido nesse contexto como uma segunda língua. 
A partir de então, o cinema torna-se texto, espaço para os alunos empreenderem sua própria interpretação para o que foi estudado, discutir e criar a partir de sua experiência de leitura, significando e re-inventando sua própria história.

Além disso, a partir do trabalho com o cinema, há uma valorização dos alunos, uma vez que é a interpretação deles para a história que irá ser filmada, momento em que precisam tomar decisões, escolher em conjunto sua forma de contar o que foi visto, seu olhar sobre o texto.

Por conseguinte, há um espaço de socialização das atividades, já que é preciso uma equipe para realizar todas as etapas do processo de produção de um filme. Para isso, cada um torna-se responsável por uma tarefa específica, de acordo com os seus interesses, tentando respeitar o seu ritmo de aprendizagem, seu conhecimento acumulado sobre o assunto, exercitando sua capacidade de expressar opiniões, de compreender e participar das discussões envolvendo a leitura do texto. Desse modo, é o sucesso de cada um que irá garantir o sucesso do grupo, então há uma grande cobrança entre eles, bem como um maior envolvimento e empenho para realizar “o filme” que irá representar o resultado final da atividade.

Assim, “entender, analisar criticamente e contextualizar” são habilidades necessárias à leitura de mundo, à compreensão da realidade que nos cerca e algumas das habilidades desenvolvidas nas aulas de literatura. Paixão pelos textos, envolvimento nas discussões, ampliação do conhecimento de mundo, crescimento pessoal e intelectual, melhor auto-estima, possibilidade de aprendizagem de fato.

\section{Observações finais}

É importante ressaltar que o trabalho realizado com os alunos surdos poderia ser adaptado e utilizado também com diferentes alunos, sejam surdos ou ouvintes. Além disso, a proposta de se ensinar literatura, por meio do uso de novas tecnologias, tais como o cinema, por exemplo, torna-se um possível caminho para despertar o interesse dos alunos pela leitura e também pelos livros.

Assim, diferentes recursos, em diferentes suportes, podem e devem ser aproveitados, principalmente com utilização de diferentes adaptações dos textos clássicos, sejam em filmes, histórias em quadrinhos, edições melhor elaboradas, com materiais ricos 
em ilustrações, o que pode tornar o ensino mais atraente e funcionar como uma forma de incentivo para a leitura, aguçando a curiosidade, promovendo a discussão e a circulação do texto literário entre os jovens leitores.

\section{Referências}

BARTHES, Roland. O prazer do texto. Trad: J. Guinsburg. São Paulo: Perspectiva, 1994. CALVINO, Ítalo. Por que ler os clássicos. Trad: Nilson Moulin. São Paulo: Companhia da Letras, 2007.

FILHO, Leodegário A. de Azevedo. Pequenas reflexões sobre a desejável crise de leitura. In: Letras. Revista da Faculdade de Letras da UFRJ. Rio de Janeiro, FL / UFRJ, 1993, outubro, n 4 , p. $102-109$.

LDB - Leis de Diretrizes e Bases da Educação Nacional. LEI N ${ }^{0}$. 9.394, de 20 de dezembro de 1996. D.O. U. de 23 de dezembro de 1996.

PENNAC, Daniel. Como um romance. Trad: Leny Werneck. Rio de Janeiro: Rocco, 2008. 